\title{
Iron requirements and uptake strategies of the globally abundant marine ammonia-oxidising archaeon, Nitrosopumilus maritimus SCM1
}

\author{
Roxana T. Shafiee $\mathbb{( I}^{1} \cdot$ Joseph T. Snow $\mathbb{1}^{1} \cdot$ Qiong Zhang $^{1} \cdot$ Rosalind E. M. Rickaby $^{1}$
}

Received: 14 December 2018 / Revised: 4 April 2019 / Accepted: 15 April 2019 / Published online: 10 May 2019

(c) The Author(s) 2019. This article is published with open access

\begin{abstract}
Ammonia-oxidising archaea (AOA) mediate the rate-limiting step of nitrification, the central component of the marine nitrogen cycle that converts ammonia to nitrite then nitrate. Competition with phytoplankton for ammonium and light inhibition are considered to restrict AOA activity to below the photic zone, but observations of surface nitrification now demand a further understanding of the factors driving AOA distribution and activity. Pico- to nanomolar concentrations of iron $(\mathrm{Fe})$ limit the growth of microorganisms in a significant portion of the world's surface oceans, yet there is no examination of the role of $\mathrm{Fe}$ in $\mathrm{AOA}$ growth despite the process of ammonia oxidation being considered to rely on the micronutrient. Here we investigate the $\mathrm{Fe}$ requirements and $\mathrm{Fe}$ uptake strategies of the Nitrosopumilus maritimus strain SCM1, a strain representative of globally abundant marine AOA. Using trace metal clean culturing techniques, we found that $N$. maritimus growth is determined by $\mathrm{Fe}$ availability, displaying a free inorganic $\mathrm{Fe}\left(\mathrm{Fe}^{\prime}\right)$ half saturation constant $1-2$ orders of magnitude greater for cell growth than numerous marine phytoplankton and heterotrophic bacterial species driven by a reduced affinity for $\mathrm{Fe}^{\prime}$. In addition, we discovered that whilst unable to produce siderophores to enhance access to $\mathrm{Fe}, N$. maritimus is able to use the exogenous siderophore desferrioxamine B (DFB), likely through a reductive uptake pathway analogous to that demonstrated in phytoplankton. Our work suggests AOA growth in surface waters may be $\mathrm{Fe}$ limited and advances our understanding of AOA physiology on the cellular and mechanistic levels with implications for ecosystem dynamics and the biogeochemical N-cycle.
\end{abstract}

\section{Introduction}

Ammonia oxidation is the first and rate-limiting step of nitrification, mediated by ammonia-oxidising bacteria and archaea (AOB and AOA). Nitrification links the reduced and oxidised components of the nitrogen $(\mathrm{N})$ cycle through the conversion of ammonium $\left(\mathrm{NH}_{4}^{+}\right)$to nitrite $\left(\mathrm{NO}_{2}{ }^{-}\right)$and then nitrate $\left(\mathrm{NO}_{3}{ }^{-}\right)$. Greater ratios of $\mathrm{NO}_{3}$ to $\mathrm{NH}_{4}$ in surface waters are shown to promote the growth of faster-sinking microphytoplankton (such as diatoms) relative to

Supplementary information The online version of this article (https:// doi.org/10.1038/s41396-019-0434-8) contains supplementary material, which is available to authorized users.

Roxana T. Shafiee

roxana.shafiee@earth.ox.ac.uk

1 Department of Earth Sciences, University of Oxford, South Parks Road, Oxfordshire OX1 3AN, UK picophytoplankton, thereby driving increased carbon export to the deep ocean [1-5]. Nitrification rates also have a climatic impact through the release of the by-product nitrous oxide $\left(\mathrm{N}_{2} \mathrm{O}\right)$, a potent greenhouse gas $[6,7]$. In the oceans AOA, belonging to the phylum Thaumarchaeota, largely outnumber their bacterial counterparts $[8,9]$ and are among the most ubiquitous and abundant microbes, constituting $~ 20 \%$ of total marine prokaryotic cells [10]. Due to their key role in N-biogeochemical cycling, investigation has focused on understanding the factors that determine the distribution of Thaumarchaeota and nitrification rates throughout the water column. Photoinhibition of AOA [11-14] and competition with phytoplankton for $\mathrm{NH}_{4}^{+}$[15-17] have both been evoked as explanations of why peak nitrification rates typically occur at the base of the euphotic zone. However, observations of high nitrification rates in the euphotic zone indicate that this is not universally the case [18], suggesting that our understanding of the factors shaping the distribution of AOA is incomplete. No studies to date have directly examined the role of the trace metal iron $(\mathrm{Fe})$ in Thaumarchaeota growth, 
despite a vast body of evidence showing that $\mathrm{Fe}$ influences the growth of a range of marine $\mathrm{N}$-cycling microorganisms in a significant portion of the world's oceans $[19,20,21]$. The only study to date to directly examine the role of trace metals in Thaumarchaeota growth, demonstrated that the marine model species Nitrosopumilus maritimus (strain SCM1) has a high copper requirement, driven by numerous multi-Cu oxidases and blue $\mathrm{Cu}$-proteins resembling sulpho- and plastocyanin enzymes $[22,23]$. In contrast, $\mathrm{AOB}$ utilise a greater number of Fe-based enzymes and fewer $\mathrm{Cu}$-proteins [24] suggesting that $\mathrm{AOB}$ may possess a lower $\mathrm{Cu}$ requirement. Whether oceanic metal availability shapes the ecological niche separation of $\mathrm{AOB}$ vs. AOA, in a similar way to ammonium $[25,26]$ in the oligotrophic oceans has yet to be explored. In addition, it remains unknown which $\mathrm{Fe}-$ substrates are available for uptake by $N$. maritimus, the strategies $N$. maritimus employs to gain access to low levels of $\mathrm{Fe}$ in the oceans, and how together these phenotypic traits may influence the distribution of AOA throughout the water column. In order to aid in $\mathrm{Fe}$ acquisition, some marine microorganisms produce high affinity iron(III) binding ligands called siderophores, which acts to increase the bioavailability of Fe to some microorganisms [27]. The ability of microbes to utilise different classes of siderophores, taken up either by siderophore specific membrane channels or by reduction of Fe-chelates [28-30], can provide microorganisms with a competitive advantage in iron-poor niches of the ocean.

Here we use trace metal clean culture techniques to examine the role of $\mathrm{Fe}$ in the growth of $N$. maritimus strain SCM1 with the aim of understanding how $\mathrm{Fe}$ in the oceans may drive the distribution of marine AOA species. We specifically probe the role of environmentally important $\mathrm{Fe}$ substrates in AOA growth including unchelated inorganic $\mathrm{Fe}\left(\mathrm{Fe}^{\prime}\right)$ and organic siderophore bound Fe. Our study is the first to shed light on the role of $\mathrm{Fe}$ in AOA growth, presenting implications for how $\mathrm{Fe}$ in the marine environment may shape the ecological niche that AOA occupy in the water column.

\section{Materials and methods}

\section{Archaeal cultures and growth media}

Polycarbonate culture vessels and culturing apparatus were acid cleaned $(10 \% \mathrm{HCl} v / \mathrm{v}, 24 \mathrm{~h})$ and $\mathrm{UV}$-sterilised prior to use. Triplicate cultures of Nitrosopumilus maritimus strain SCM1 (herein referred to as SCM1) were grown in SCM medium [31] and maintained at $28{ }^{\circ} \mathrm{C}$ in the dark. Macronutrients used in media preparation were treated with Chelex-100 resin (BioRad, Watford, UK) to remove trace metal contaminants [32]. The final $\mathrm{pH}$ of the media was 7.5. To investigate the effect of unchelated inorganic $\mathrm{Fe}$ concentration $\left(\left[\mathrm{Fe}^{\prime}\right]\right)$ on SCM1 growth, ethylenediamine tetraacetic acid (EDTA; Merck, Darmstadt, Germany) was used to buffer Fe and other metals in cultures; $\left[\mathrm{Fe}^{\prime}\right]$ was controlled by varying the addition of $\mathrm{FeCl}_{3}$ and maintaining a constant concentration of EDTA at $12 \mu \mathrm{mol} \mathrm{L}{ }^{-1}$. We did not observe difference in growth rate in cultures with equivalent $\left[\mathrm{Fe}^{\prime}\right]\left(7500 \mathrm{pmol} \mathrm{\textrm {L } ^ { - 1 }}\right)$ but with varying [EDTA]; cultures with $12 \mu \mathrm{mol} \mathrm{L} \mathrm{L}^{-1}$ EDTA, relative to regular SCM media with $7.5 \mu \mathrm{mol} \mathrm{L^{-1 }}$ [EDTA], did not produce an inhibitory effect (data not shown). [ $\left.\mathrm{Fe}^{\prime}\right]$ in cultures was calculated using Visual Minteq software [33], including background $\mathrm{Fe}$ contamination of $50 \mathrm{nmol} \mathrm{L}^{-1}$ from basal SCM medium with included macronutrients and vitamins but without added trace metals, determined using inductively coupled plasma mass spectrometry [34]. Cultures were acclimated to metal concentrations stated by transferring cultures consecutively into new media until growth rates did not vary with statistical significance (ANOVA, $p<0.05$ ).

Growth was determined by measuring concentrations of nitrite $\left(\left[\mathrm{NO}_{2}{ }^{-}\right]\right)$spectrophotometrically [35], which was observed to correlate with cell counts at both high and low $\left[\mathrm{Fe}^{\prime}\right]$ (Supplementary Fig. 1). Specific growth rate $\left(\mathrm{d}^{-1}\right)$ was calculated over the linear phase of semi-log plots of nitrite concentration over time. SCM1 and published phytoplankton and marine heterotrophic bacterial growth rate data [36-43] in response to $\left[\mathrm{Fe}^{\prime}\right]$ were fit to a Monod function:

$\mu=\frac{\mu_{\max } \cdot\left[\mathrm{Fe}^{\prime}\right]}{K_{s}+\left[\mathrm{Fe}^{\prime}\right]}$

Whereby $\mu$ is growth rate $\left(\mathrm{d}^{-1}\right), \mu_{\max }$ is maximum growth rate, $\left[\mathrm{Fe}^{\prime}\right]$ is the concentration of unchelated inorganic $\mathrm{Fe}$ and $K_{s}$ is the growth half saturation constant.

\section{Calculation of steady state uptake rate constant}

In order to compare the Fe-uptake rates of SCM1 with published uptake rates of other marine microorganisms compiled in our study ([28, 30, 37, 44-49]; Supplementary Table 1), we calculated the steady state uptake rate $\left(\rho_{\mathrm{ss}}\right)$ in mol Fe per cell $\mathrm{h}^{-1}$ and steady state uptake constant $\left(K_{\text {in }}\right)$ in $\mathrm{L} \mathrm{cell}^{-1} \mathrm{~h}^{-1}$ as defined in [29]. Cell numbers used in our calculations were obtained by using a conversion factor of $6.01 \times 10^{10}$ cells per mol $\mathrm{NO}_{2}^{-}$derived from measurements of cell counts with increasing $\left[\mathrm{NO}_{2}^{-}\right]$(Supplementary Fig. 1).

$\rho_{s S}=Q \cdot \mu$

$K_{\text {in }}=\frac{\rho_{s s}}{[S]}$

Whereby $Q$ is equal to the cellular Fe quota $\left(\mathrm{mol} \mathrm{Fe}\right.$ cell $^{-1}$ ), $\mu$ is specific growth rate $\left(\mathrm{h}^{-1}\right)$ and $S$ is the concentration of $\mathrm{Fe}$ substrate (either $\mathrm{Fe}^{\prime}$ or $\left.\mathrm{FeDFB}\right)\left(\mathrm{mol} \mathrm{L}^{-1}\right)$. Furthermore, we were able to normalise the uptake rate constant to cell 
surface area $\left(K_{\text {in }} /\right.$ S.A. $)$ in order to obtain an uptake constant independent of cell surface area and therefore proportional to the affinity of the uptake system. SCM1 surface area was calculated based on average dimensions of cells imaged using scanning electron microscopy (Supplementary Methods). SCM1 cells were rod-shaped with a diameter of $0.1-0.2 \mu \mathrm{m}$ and length of $0.45-0.58 \mu \mathrm{m}$ (Supplementary Fig. 2); cell surface area was calculated using an average diameter of $0.15 \mu \mathrm{m}$ and length of $0.52 \mu \mathrm{m}$. These dimensions agree with the previous analyses of SCM1 size [31], which showed rod-shaped cells with a diameter of $0.17-22 \mu \mathrm{m}$ and length of $0.5-9 \mu \mathrm{m}$. All steady state uptake constants used in our comparison were compiled and calculated by Lis et al. [30] from published datasets (Supplementary Table 2).

\section{Siderophore production and Fe-complex uptake pathway}

To examine whether SCM1 is able to grow using siderophore bound Fe, SCM1 was cultured in medium with the addition of desferrioxamine B mesylate (DFB; Merck), a fungal siderophore that has a greater stability constant $\left(\log \mathrm{K}_{\mathrm{FeL}, \mathrm{Fe}^{\prime}}^{\prime}=11.8\right)$ for $\mathrm{Fe}$ (III) compared with EDTA $\left(\log \mathrm{K}_{\mathrm{FeL}^{\prime}, \mathrm{Fe}^{\prime}}=8.6, \mathrm{pH} 8\right)$ $[50,51]$. $\left[\mathrm{Fe}^{\prime}\right]$ in DFB buffered media was calculated using the equation $\left[\mathrm{Fe}^{\prime}\right]=[\mathrm{FeDFB}] /\left(\left[\mathrm{DFB}^{\prime}\right] \times\left[\mathrm{K}_{\mathrm{Fe}^{\prime} \mathrm{DFB}}{ }^{\text {cond }}\right]\right)$. A 1.3 -fold excess of DFB was added over Fe, resulting in $\left[\mathrm{Fe}^{\prime}\right]$ of $5.2 \times$ $10^{-9}$ pmol L ${ }^{-1}$, considered to be negligible, thereby making $\mathrm{Fe}$ bound to DFB (FeDFB) the main Fe substrate in these experiments. EDTA concentrations were kept constant at $12 \mu \mathrm{mol} \mathrm{L}{ }^{-1}$ EDTA to buffer other trace metals as done in previous studies [46, 47].

Siderophore secretion by SCM1 was tested using a liquid Chrome Azurol S (CAS) assay [52]. Prior to this assay, potential siderophores were preconcentrated from the supernatant of 300 and $1050 \mathrm{pmol} \mathrm{L}^{-1} \mathrm{Fe}^{\prime}$ cultures (grown in the absence of EDTA), using Solid Phase Extraction (SPE) cartridges (Isolute ENV+, 1 g $25 \mathrm{~mL}$, Biotage, Hengoed, UK). Cartridges were precleaned with $5 \mathrm{ml}$ methanol and $5 \mathrm{ml} 11.2 \mathrm{mmol} \mathrm{L}^{-1}$ ammonium carbonate (pH 7.5). One litre of $0.1 \mu \mathrm{m}$-filtered culture supernatant was passed through the column at a flow rate of $8 \mathrm{ml} \mathrm{min}^{-1}$, followed by $5 \mathrm{ml}$ of $11.2 \mathrm{mmol} \mathrm{L}^{-1}$ ammonium carbonate to remove salts. Siderophores were eluted with $5 \mathrm{ml}$ of 1:20:80 (v/v/v) formic acid/water/methanol. The SPE eluent from all samples was dried under high purity $\mathrm{N}_{2}$ to $100 \mu \mathrm{L}$ and then made up to $500 \mu \mathrm{L}$ with $0.1 \%$ (v/v) formic acid (Sigma-Aldrich) prior to analysis. The sensitivity of this method was tested by preconcentrating $1 \mathrm{~L}$ of $1-100$ pmol $\mathrm{L}^{-1}$ DFB solutions, which are typically undetectable by the CAS Assay, using the SPE columns. The lowest concentration detected using this method was 10 pmol L ${ }^{-1}$ DFB, which was used as a positive control. Uninoculated EDTA-free SCM media passed through the SPE column was used as a blank. Spectra were measured between
400 and $800 \mathrm{~nm}$ and siderophore production was observed as a decrease in the absorbance peak at $630 \mathrm{~nm}$.

We used the ferrozine assay [29] to identify whether SCM1 adopts a reductive Fe-uptake pathway in Fe acquisition. SCM1 cultures acclimated to total $[\mathrm{Fe}]$ of $1050 \mathrm{nmol} \mathrm{L}^{-1}$ (both EDTA and DFB experiments) were treated with $200 \mu \mathrm{mol} \mathrm{\textrm {L } ^ { - 1 }}$ ferrozine (FZ; 5,6-Diphenyl-3-(2-pyridyl)-1,2,4-triazine) at the beginning of experiments. As $\mathrm{Fe}(\mathrm{II})-\mathrm{FZ}_{3}$ complexes are unavailable for uptake across the plasma membrane [53], a reduction in growth rate suggests a reductive uptake pathway is present in $\mathrm{Fe}$ acquisition. FZ concentrations used in our experiments are shown to be suitable in binding ferrous iron without inducing abiotic reduction of Fe(III) species [54]. All Fe-uptake experiments were performed in the dark to prevent the photoreduction of $\mathrm{Fe}(\mathrm{III})$ chelates.

\section{Cellular Fe and P content}

All samples and reagents were processed using trace metal clean techniques and acid washed plastic wear $(10 \% \mathrm{HCl}$ $\mathrm{v} / \mathrm{v}, 24 \mathrm{~h}$ ) in a clean laboratory prior to trace element analysis. SCM1 cells cultured in 300,550 and $1050 \mathrm{pmol} \mathrm{L}^{-1}$ $\mathrm{Fe}^{\prime}$ were harvested in late exponential phase by centrifugation at $5000 \times \mathrm{g}$ for $25 \mathrm{~min}$ and then rinsed with Chelex-100 treated SCM media to remove weakly bound surface metals. Cells were digested in acid-cleaned Teflon as follows: refluxing at $100{ }^{\circ} \mathrm{C}$ with $16 \mathrm{~N}$ quartz distilled (q.d.) $\mathrm{HNO}_{3}$ (produced in-house) and $\mathrm{H}_{2} \mathrm{O}_{2}$ (ROMIL $\mathrm{UpA}^{\mathrm{TM}}$, Cambridge, UK) in a ratio of $3: 2$ overnight. The liquid was then allowed to evaporate to dryness and $2 \%$ q.d. $\mathrm{HNO}_{3}$ was added to reflux for an hour to resuspend the dried samples. ${ }^{56} \mathrm{Fe}$ and ${ }^{31} \mathrm{P}$ concentrations were determined using a Quadrupole ICP-MS Perkin Elmer NexION 350 with Elemental Scientific Flow Injection Auto-sampler (FIAS) in a method optimised for high salt matrixes [34].

\section{Fe rescue experiments}

In order to confirm whether Fe limits SCM1 growth in EDTAbuffered experiments, we performed an "Fe rescue" of experiments, which showed suppressed or no cell growth in the second sub-culture before cultures had become fully acclimated. We supplemented 50 and $150 \mathrm{pmol} \mathrm{L}^{-1} \mathrm{Fe}$ cultures with additional $\mathrm{FeCl}_{3}$ at $120 \mathrm{~h}$ resulting in final $\left[\mathrm{Fe}^{\prime}\right]$ of $1050 \mathrm{pmol} \mathrm{L}^{-1}$. Control cultures received no additional $\mathrm{FeCl}_{3}$.

\section{Data analysis}

All statistical analyses were performed using Minitab v.13.1. Data were examined for normality and equal variance prior to student's $t$-test and analysis of variance (ANOVA) statistical tests. Significant results are reported at the 95\% confidence level $(p<0.05)$. 

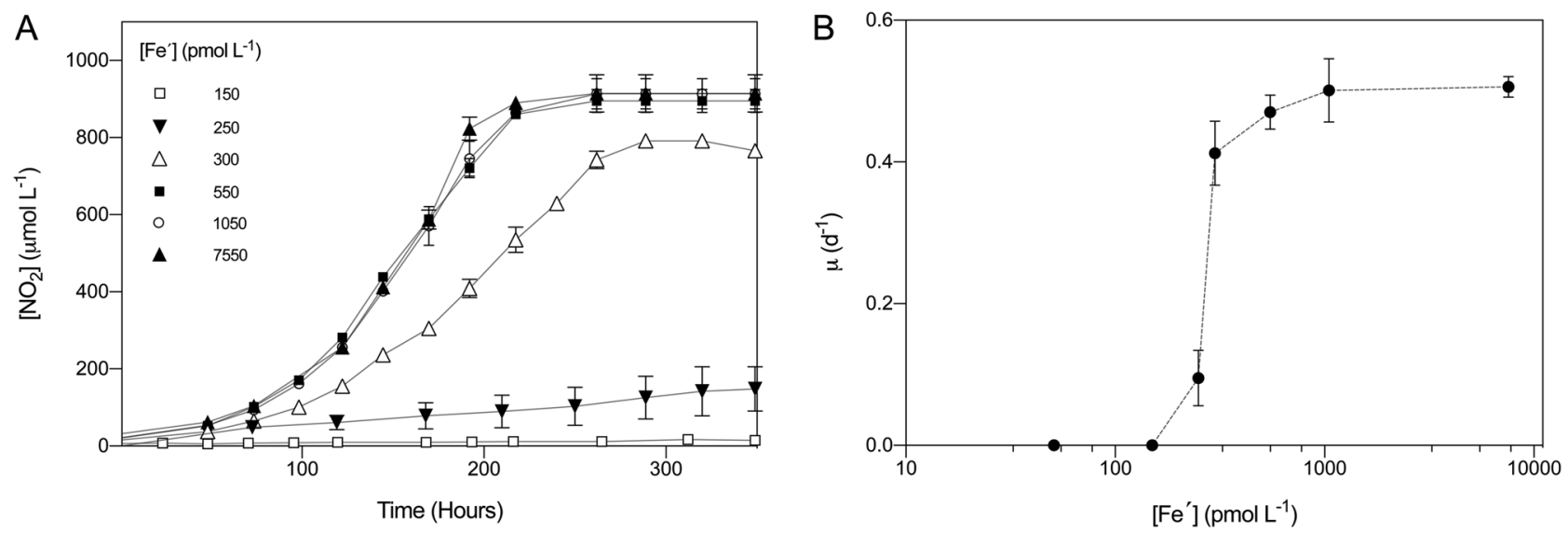

Fig. 1 Effect of unchelated inorganic $\mathrm{Fe}$ concentration $\left[\left(\mathrm{Fe}^{\prime}\right)\right]$ on $\mathrm{NO}_{2}{ }^{-}$production and specific growth rate $(\mu)$ of SCM1. Error bars indicate standard deviation, $n=20$

\section{Results}

\section{Effect of unchelated $\mathrm{Fe}$ ion $\left(\mathrm{Fe}^{\prime}\right)$ on total nitrite production and specific growth rates}

Cultures of SCM1 were acclimated to a range of unchelated inorganic $\mathrm{Fe}$ concentrations $\left(\left[\mathrm{Fe}^{\prime}\right]\right)$, as described above. Treatments with $<250$ pmol L ${ }^{-1} \mathrm{Fe}^{\prime}$ did not support SCM1 growth as evidenced by a total lack of $\mathrm{NO}_{2}{ }^{-}$production (Fig. 1a). We observed SCM1 growth in all tested conditions $\geq 250 \mathrm{pmol} \mathrm{L} \mathrm{L}^{-1} \mathrm{Fe}^{\prime}$. Treatments at 250 and $300 \mathrm{pmol} \mathrm{L} \mathrm{L}^{-1} \mathrm{Fe}^{\prime}$ showed suppressed growth curves, producing significantly lower final $\left[\mathrm{NO}_{2}{ }^{-}\right](p<0.05)$, compared with $550-7550 \mathrm{pmol} \mathrm{L}^{-1} \mathrm{Fe}^{\prime}$ cultures, which produced indistinguishable growth curves and maximum $\left[\mathrm{NO}_{2}^{-}\right]$reached.

To provide confirmation that growth inhibition was due to Fe limitation, we supplemented cultures showing little and or no growth in the second experimental sub-culture (where cultures were experiencing $\mathrm{Fe}$ stress but before they had become acclimated) with $\mathrm{FeCl}_{3}$ to reach a final $\left[\mathrm{Fe}^{\prime}\right]$ of $1050 \mathrm{pmol} \mathrm{L}^{-1}$ (Supplementary Fig. 3). We observed enhanced $\mathrm{NO}_{2}{ }^{-}$production in all supplemented cultures, compared with nonsupplemented controls; $150 \mathrm{pmol} \mathrm{L}{ }^{-1} \mathrm{Fe}^{\prime}$ treatments supple-

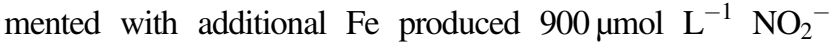

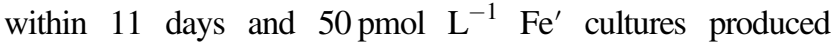
$900 \mu \mathrm{mol} \mathrm{L}{ }^{-1} \mathrm{NO}_{2}^{-}$within 15 days.

Maximum specific growth rates, $\mu_{\max }$, were observed in 7550 pmol L ${ }^{-1} \mathrm{Fe}^{\prime}$ treatments (Table 1). The half saturation constant $\left(K_{s}\right)$, based on a Monod curve fitted to our data (eq.1) was $361.5 \mathrm{pmol} \mathrm{L}{ }^{-1} \mathrm{Fe}^{\prime}$. Specific growth rate $(\mu)$ varied significantly between 250 and 1050 pmol L ${ }^{-1} \mathrm{Fe}^{\prime}$ treatments $(p<$ 0.05), ranging between 27-99\% of $\mu_{\max }$ (Table 1; Fig. 1b). Cultures treated with $250 \mathrm{pmol} \mathrm{L}{ }^{-1} \mathrm{Fe}^{\prime}$ grew at the lowest $\mu$ (27\% of $\mu_{\max }$ ) followed by $300 \mathrm{pmol} \mathrm{L} \mathrm{L}^{-1} \mathrm{Fe}^{\prime}$ treated cultures which grew at $81 \%$ of $\mu_{\max }$. We observed no significant increase in $\mu_{\max }$ when $\left[\mathrm{Fe}^{\prime}\right]>1050 \mathrm{pmol} \mathrm{L}^{-1}(p>0.05)$, suggesting that these cultures were Fe-replete.

\section{Cellular iron quotas}

Cellular Fe and $\mathrm{P}$ concentrations were measured in response to increasing $\left[\mathrm{Fe}^{\prime}\right]$, between $300-7550 \mathrm{pmol} \mathrm{L}^{-1} \mathrm{Fe}^{\prime}$. We observed a scaling between SCM1 cellular Fe and P concentrations, $\left[\mathrm{Fe}^{\prime}\right]$ and $\mu$ (Table 1 ). Fe:P varied significantly between treatments growing at different $\mu(p<0.05)$, ranging between $11.4( \pm 4.7)$ and $199.95( \pm 4.9) \mathrm{mmol} \mathrm{Fe} \mathrm{mol}^{-1} \mathrm{P}$. We observed maximum cellular Fe:P in cultures growing at $\mu_{\max }$.

\section{Steady state uptake rate of $\mathrm{Fe}^{\prime}$ and FeDFB}

A requirement of steady state uptake rate $\left(\rho_{\mathrm{ss}}\right)$ calculations is for cellular Fe quota and specific growth rates to be used when $\left[\mathrm{Fe}^{\prime}\right]$ is limiting to growth. We therefore calculated $\rho_{s s}$ based on the cellular Fe concentration of SCM1 treatments at 300 and $550 \mathrm{pmol} \mathrm{L}^{-1} \mathrm{Fe}^{\prime}$, that were growing at 81 and $93 \%$ of $\mu_{\max } . \mathrm{Fe}^{\prime}$ uptake rate was $1.1 \times 10^{-22} \mathrm{~mol} \mathrm{Fe}$ cell $^{-1} \mathrm{~h}^{-1}\left( \pm 3.1 \times 10^{-23}\right)$ and the $\mathrm{Fe}^{\prime}$ uptake rate constant, $K_{\text {in }}\left(\rho_{\text {ss }}\right.$ normalised to $\left.\left[\mathrm{Fe}^{\prime}\right]\right)$ was $4.5 \times 10^{-13} \mathrm{~L} \mathrm{cell}^{-1} \mathrm{~h}^{-1}$ $\left( \pm 1.2 \times 10^{-13}\right)$. The uptake rate of FeDFB was significantly lower than $\mathrm{Fe}^{\prime}(p<0.05)$ at $2.8 \times 10^{-21} \mathrm{~L} \mathrm{cell}^{-1} \mathrm{~h}^{-1}( \pm 1.6 \times$ $10^{-22}$ ) equating to an uptake rate constant of $2.8 \times 10^{-15}$ $\mathrm{L} \mathrm{cell}^{-1} \mathrm{~h}^{-1}\left( \pm 1.6 \times 10^{-16}\right)$.

\section{SCM1 siderophore production and FeDFB uptake}

We conducted a CAS assay to determine whether SCM1 produces siderophores. In this assay, there was no evidence for siderophore production in the medium of either $300 \mathrm{pmol} \mathrm{L} \mathrm{L}^{-1}$ or $1050 \mathrm{pmol} \mathrm{L}^{-1} \mathrm{Fe}^{\prime}$ treatments, as the 
Table 1 Relationships between Total $[\mathrm{Fe}]$, [Fe'], cellular Fe and P concentration, specific growth rate $(\mu)$ and relative growth rate $\left(\mu / \mu_{\max }\right)$. Values in parentheses represent standard deviation

\begin{tabular}{|c|c|c|c|c|c|c|}
\hline$[\mathrm{Fe}]\left(\mathrm{nmol} \mathrm{L}^{-1}\right)$ & {$\left[\mathrm{Fe}^{\prime}\right]\left(\mathrm{pmol} \mathrm{L}^{-1}\right)$} & $\mathrm{Fe}\left(\mathrm{pmol} \mathrm{cell}^{-1}\right)$ & $\mathrm{P}\left(\mathrm{pmol} \mathrm{cell}^{-1}\right)$ & $\mathrm{Fe}: \mathrm{P}\left(\mathrm{mmol} \mathrm{mol}{ }^{-1}\right)$ & $\mu\left(d^{-1}\right)$ & $\mu / \mu_{\max }$ \\
\hline 200 & 200 & & & & 0 & 0 \\
\hline 250 & 250 & & & & $0.13( \pm 0.05)$ & $0.27( \pm 0.02)$ \\
\hline 300 & 300 & $5.0 \times 10^{-6}\left( \pm 4.3 \times 10^{-6}\right)$ & $5.5 \times 10^{-4}\left( \pm 1 \times 10^{-4}\right)$ & $11.4( \pm 4.7)$ & $0.41( \pm 0.05)$ & $0.81( \pm 0.09)$ \\
\hline 550 & 550 & $6.5 \times 10^{-6}\left( \pm 1.3 \times 10^{-6}\right)$ & $3.3 \times 10^{-4}\left( \pm 5.4 \times 10^{-5}\right)$ & $18.8( \pm 3.2)$ & $0.47( \pm 0.02)$ & $0.93( \pm 0.05)$ \\
\hline 1050 & 1050 & $1.1 \times 10^{-4}\left( \pm 4.2 \times 10^{-5}\right)$ & $2.6 \times 10^{-3}\left( \pm 1.2 \times 10^{-4}\right)$ & $39.3( \pm 11.8)$ & $0.50( \pm 0.01)$ & $0.99( \pm 0.09)$ \\
\hline 7550 & 7550 & $0.78( \pm 0.07)$ & $3.93( \pm 0.05)$ & $199.95( \pm 4.9)$ & $0.51( \pm 0.01)$ & $1( \pm 0.02)$ \\
\hline
\end{tabular}

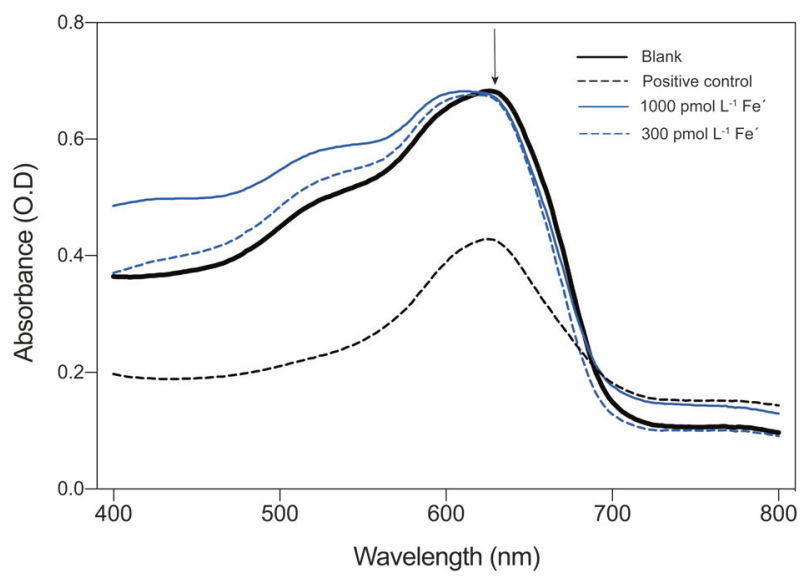

Fig. 2 Absorbance spectra of SCM1 culture supernatant with 300 (blue dashed line) and $1050 \mathrm{pmol} \mathrm{L}^{-1} \mathrm{Fe}$ (blue solid line) measured between $400-800 \mathrm{~nm}$ following treatment with Chrome Azurol S (CAS) assay solution. Siderophore production was denoted as a decrease in absorbance from the blank (uninoculated SCM medium-black solid line) at $630 \mathrm{~nm}$, marked with an arrow. $10 \mathrm{pmol} \mathrm{L}^{-1} \mathrm{DFB}$ solution was used as a positive control (see methods for further details)

absorbance spectra of culture supernatants did not differ significantly from the blank (Fig. 2). However, this result does not completely rule out the production of very low concentrations $\left(<10\right.$ pmol $\mathrm{L}^{-1}$ detection limit $)$ of siderophores by SCM1. The ability of SCM1 to grow using siderophore bound $\mathrm{Fe}$ was examined using growth media wherein all $\mathrm{Fe}$ was bound to the hydroxamate siderophore, DFB (FeDFB), which reduces $\left[\mathrm{Fe}^{\prime}\right]$ to negligible concentrations (see Methods). We observed no SCM1 growth at $150 \mathrm{nmol} \mathrm{L} \mathrm{L}^{-1} \mathrm{FeDFB}$. Only treatments with $1050 \mathrm{nmol} \mathrm{L}^{-1}$ FeDFB displayed SCM1 growth, reaching $\mu$ of $0.44 \mathrm{~d}^{-1}$ (Fig. 3); however, this is significantly lower than with EDTA-buffered treatments with $1050 \mathrm{pmol} \mathrm{L}^{-1}$ $\mathrm{Fe}^{\prime}(p<0.05)$, which reached $\mu$ of $0.50 \mathrm{~d}^{-1}$.

\section{The role of reduction in Fe uptake}

In order to determine whether reduction of $\mathrm{Fe}$ (III) to $\mathrm{Fe}$ (II) is a component of SCM1 Fe acquisition, we examined the effect of ferrozine (FZ) addition on SCM1 growth rate. FZ significantly

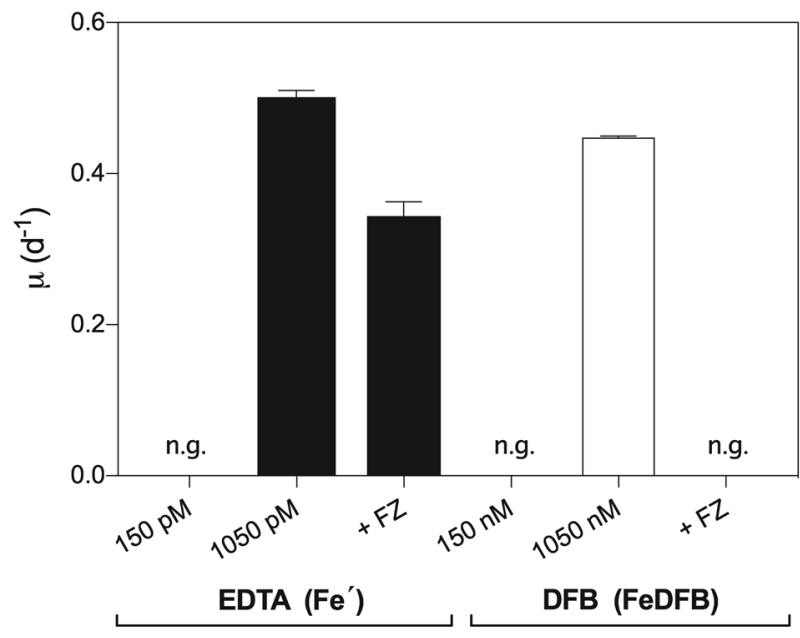

Fig. 3 Effect of Fe on SCM1 specific growth rate $(\mu)$ in EDTAbuffered experiments wherein the available substrate is $\mathrm{Fe}^{\prime}$ (solid bars) and DFB buffered experiments wherein there is negligible $\mathrm{Fe}^{\prime}$ and all $\mathrm{Fe}$ is bound to DFB (FeDFB - open bars), and effect of Fe(II) specific chelator, ferrozine (FZ) on specific growth rates of SCM1 in these cultures $(+\mathrm{FZ})$. n.g. indicates no SCM1 growth. Concentrations on $x$ axis indicate the available substrate (i.e. Fe' or FeDFB). Error bars indicate standard deviation, $n=11$

reduced $\mu$ in both EDTA and DFB buffered cultures $(p<0.05)$, compared with the untreated controls (Fig. 3) suggesting a requirement for $\mathrm{Fe}$ (III) reduction in Fe uptake. In EDTA treatments, addition of $\mathrm{FZ}$ reduced $\mu$ by $30 \%$, compared to DFB treatments whereby FZ reduced $\mu$ by $100 \%$.

\section{Discussion}

\section{SCM1 has an elevated $K_{\mathrm{s}}$ compared with marine phytoplankton driven by a reduced affinity for $\mathrm{Fe}^{\prime}$}

In order to place our results into the context of the microbial community, we compared the Fe-requirements of SCM1 with published datasets of a range of environmentally important marine microorganisms (Fig. 4). There is a great wealth of data surrounding the role of $\mathrm{Fe}$ on marine phytoplankton growth, motivated by the finding that iron limits primary productivity in 
A

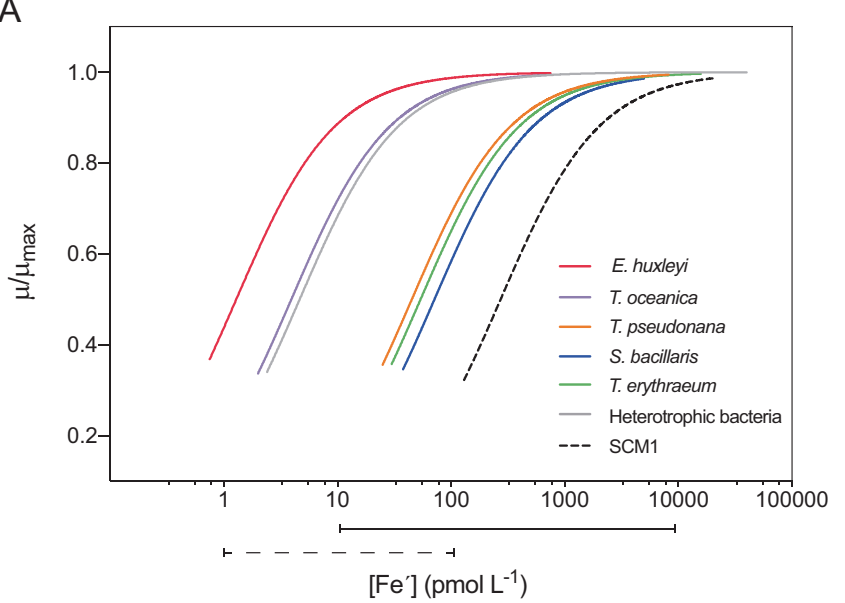

C

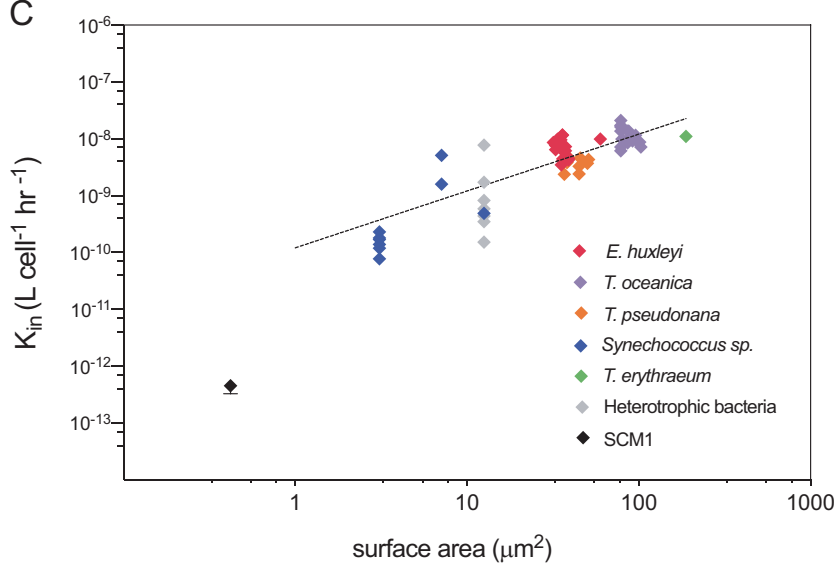

Fig. 4 a Monod curves fitted to compiled phytoplankton and heterotrophic bacteria data showing the effect of [ $\left.\mathrm{Fe}^{\prime}\right]$ on relative growth rate $\left(\mu / \mu_{\max }\right)$ compared with data from this study (SCM1). The range of oceanic total [Fe] (solid line) and [ $\left.\mathrm{Fe}^{\prime}\right]$ (dashed line) from refs. [85-92] are displayed below the plot. b Half saturation constants $\left(K_{\mathrm{s}}\right)$ based on Monod curves fitted to compiled data. $\mathbf{c} \mathrm{Fe}^{\prime}$ uptake rate $\left(\mathrm{L}\right.$ cell $\left.{ }^{-1} \mathrm{~h}^{-1}\right)$

$30 \%$ of the world's surface ocean $[55,56]$. We compared the effect of $\left[\mathrm{Fe}^{\prime}\right]$ on growth rate (including the half saturation constant, $K_{\mathrm{s}}$ ), the $\mathrm{Fe}^{\prime}$ uptake rate and critical cellular $\mathrm{Fe}: \mathrm{P}$ quota (Supplementary Methods) between published phytoplankton, marine heterotrophic bacterial datasets and SCM1 data from this study.

We observed that SCM1 displays the greatest half saturation constant $\left(K_{\mathrm{s}}\right)$ for $\mathrm{Fe}^{\prime}$ amongst the organisms assessed, despite not showing the highest critical cellular $\mathrm{Fe}$ quota (Fig. 4). In phytoplankton and marine bacteria, the critical cellular $\mathrm{Fe}$ quota (i.e. the minimal cellular $\mathrm{Fe}$ demand to reach $\mu_{\max }$-Supplementary Fig. 4) is an important determinant in $K_{\mathrm{s}}$ as surface area normalised $\mathrm{Fe}^{\prime}$ uptake rate is remarkably consistent [30]. The similarity in rate constants across a range of taxonomically diverse phytoplankton and marine bacteria reflects the selective
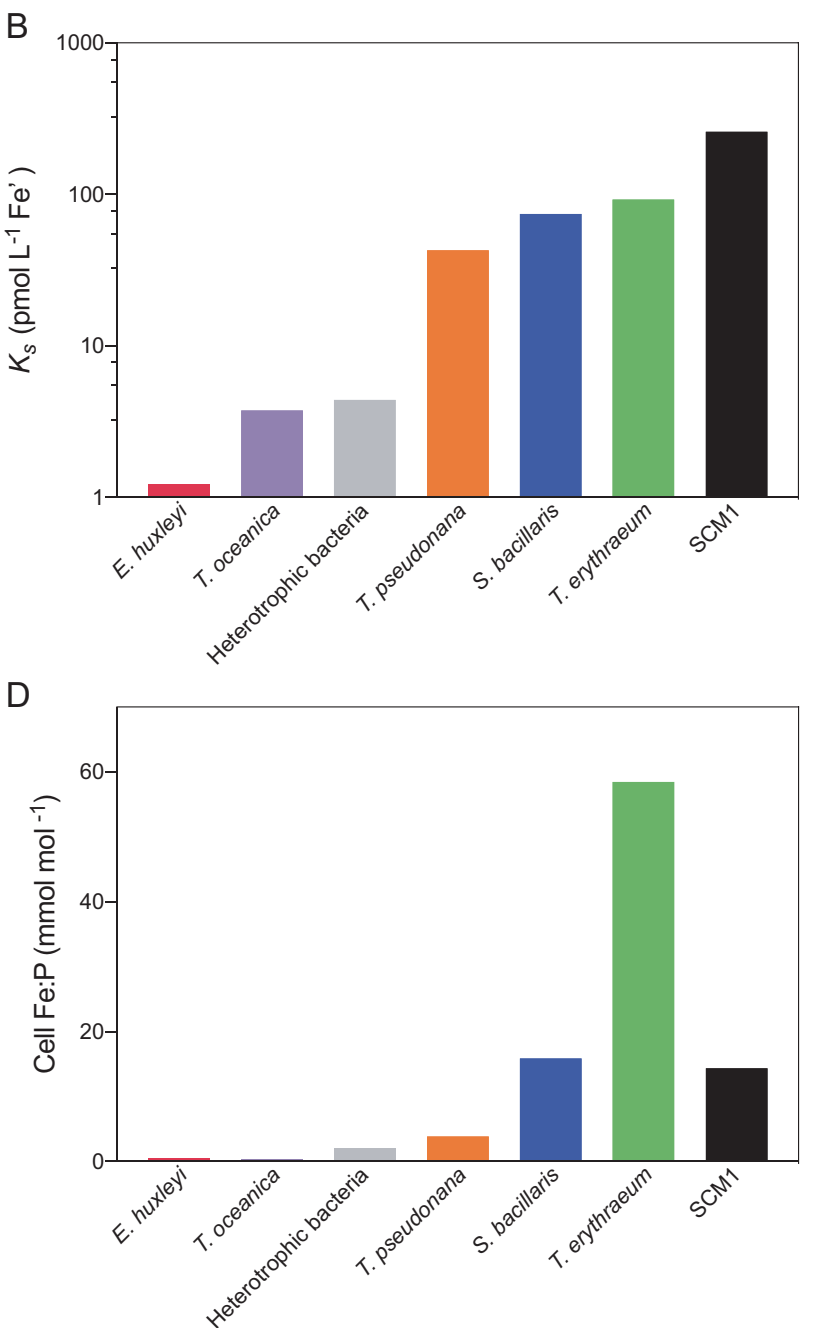

of phytoplankton, heterotrophic bacteria and SCM1 as a function of surface area. d Critical cellular Fe:P as estimated from linear regression of relative growth rate (in Fe limited cells) against cellular Fe:P (see Supplementary Methods for more detail). Published datasets and references used can be found in Supplementary Tables 1 and 2 [93, 94]

pressure placed on phytoplankton over time to evolve efficient Fe-uptake systems in environments wherein $\mathrm{Fe}$ is chronically low [57]. This is evident in the genomes of phytoplankton and heterotrophic bacteria, which commonly encode for Fe-specific membrane transport proteins (e.g. FeoA/B/C, AfuA, FTR1) in addition to general metal cation transporters [58, 59]. However, SCM1 does not follow the observed proportionality in uptake rate constants that have emerged from phytoplankton and bacterial data, displaying a reduced affinity for $\mathrm{Fe}^{\prime}$ relative to cell surface area (Fig. 4c; $p<0.05$ ). Perhaps unsurprisingly, genes encoding for $\mathrm{Fe}$-specific membrane transport proteins identified in eukaryotes and prokaryotes are absent from the genome of SCM1. Instead it appears that SCM1 only has genes encoding for generalist divalent cation transporters belonging to the Tro and ZIP $\mathrm{ABC}$ transporter families 
(Supplementary Table 3; Nmar_0328, Nmar_0330, Nmar_0331, Nmar_0329, Nmar_1130 and Nmar_1662). We therefore speculate that the high $K_{\mathrm{s}}$ of SCM1 is driven by a reduced affinity for $\mathrm{Fe}^{\prime}$ due to a lack of Fe-specific metal uptake proteins and not by a distinctly elevated critical cellular Fe quota. The only marine AOA documented to have genes for $\mathrm{Fe}$-specific membrane uptake proteins is Candidatus Nitrosopelagicus brevis str. CN25 (herein $\mathrm{Ca}$. N. brevis) (Supplementary Table 3), encoded by T478_0963. However, an initial search of the TARA metagenomic database (Supplementary Table 4 and Supplementary Fig. 5), returns a greater number of Thaumarcheotal hits for genes homologous to non-specific metal transporters homologous over $\mathrm{Ca}$. N. brevis-related $\mathrm{Fe}^{2+}$ specific transporters (FeoB encoded by gene T478_0963), suggesting that SCM1 Fe-uptake dynamics is a representative of Fe-uptake processes in marine AOA.

\section{Fe requirement of SCM1}

Our data compilation indicates that Synechococcus bacillaris and Trichodesmium erythraeum, have the greatest critical cellular Fe:P required to reach $\mu_{\max }$ (Fig. 4 and Supplementary Fig. 4). This is unsurprising in both cases: the $\mathrm{N}_{2}$-fixation capacity of $T$. erythraeum drives a high $\mathrm{Fe}$ requirement due to the Fe-rich nitrogenase proteins [60-62]; the elevated Fe:P in $S$. bacillaris compared with eukaryotic diatoms and haptophytes can be explained by a higher proportion of Fe-rich photosystem I versus photosystem II $[63,64]$. Given that SCM1 does not have photosynthetic or nitrogen fixation capabilities, our observed Fe quota may be greater than initially expected. However, proteomic analyses indicate that ferredoxin, an Fe-S protein encoded by the gene Nmar_0239, is the most highly expressed protein in exponentially growing SCM1 cells [65]. Analyses of $\mathrm{Ca}$. $\mathrm{N}$. brevis also revealed that $\mathrm{Fe}-\mathrm{S}$ proteins were among the most highly expressed genes and proteins [66, 67]. In both cases, Fe-S proteins are co-expressed with key ammoniamonoxygenase modules implying that $\mathrm{Fe}-\mathrm{S}$ proteins play a central role in the electron transport chain of Thaumarchaeota in addition to $\mathrm{Cu}$ as previously suggested [22, 23]. It is yet to be explored whether the presence of cytochromes in $\mathrm{AOB}$, drives a similar, lower or greater Fe-requirement in $\mathrm{AOB}$ in doing so influencing the niche differentiation between $\mathrm{AOB}$ and $\mathrm{AOA}$ in the oceans, in addition to ammonia affinity [25, 26].

\section{Utilisation of siderophore bound Fe through a reductive uptake pathway}

In the oceanic surface waters, $>99.9 \%$ of Fe is complexed by organic ligands [25], thereby rendering the concentration of unchelated inorganic $\mathrm{Fe}\left(\mathrm{Fe}^{\prime}\right)$ to vanishingly low concentrations and creating a requirement for photochemical or redox mechanisms to maintain an adequate supply of $\mathrm{Fe}^{\prime}$ [68]. The high [ $\left.\mathrm{Fe}^{\prime}\right]$ required to see growth in our SCM1 cultures ( $>150$ pmol L $\left.{ }^{-1} \mathrm{Fe}^{\prime}\right)$, strongly suggests that SCM1 is able to access another source of Fe in the oceans to fulfil their Fe requirements, or else AOA would unlikely be so widespread in the marine environment [10]. We observed that while SCM1 is not able to produce siderophores to enhance access to $\mathrm{Fe}$ under low [ $\left.\mathrm{Fe}^{\prime}\right]$ (Fig. 2), SCM1 can grow using Fe bound to the strong hydroxamate siderophore, DFB, likely through a reductive uptake pathway as demonstrated in range of marine phytoplankton (Fig. 3) [28, 54] or an alternative yet unknown uptake pathway. The use of a reductive Fe-uptake pathway (for both EDTA and DFB) agrees with bioinformatic evidence showing that SCM1 only has metal uptake proteins capable of divalent cation transport across the inner membranes (Supplementary Table 3), necessitating the reduction of ferric Fe-complexes before they can be imported into the cell. As our experiments were performed in the dark, we can exclude the possibility of abiotic photoreduction of organic chelates as a source of $\mathrm{Fe}$ (II) to either divalent uptake pathways and can be confident that SCM1 is actively reducing the Fe-organic complex.

Ferric reductases present in phytoplankton have been characterised [28, 54]; however, to date only one archaeal ferric reductase, from Archaeoglobus fulgidus, has been isolated and characterized [69]. The ferric reductase responsible for reducing ferric-chelates before uptake across the inner membrane has not yet been identified in SCM1. To identify candidate ferric-reductase proteins, we performed a BLASTp search of all known ferric-chelate reductases (prokaryotic and eukaryotic) against the SCM1 genome (see Supplementary Methods and Supplementary Table 5). Our search highlighted one candidate gene, Nmar_0180, which returned a significant e-value (e-value threshold defined as $\mathrm{e}^{-25}$ ) and high bit score. Nmar_0180 encodes a NADP oxidoreductase F420-dependent coenzyme (Supplementary Table 6), which shows significant sequence homology with proteins that have ferric-chelate reductase (NADPH) activity (GO: 0052851) identified from two archaea, Halobacterium salinarum and Methanocaldococcus jannaschii. Further work on isolating and characterizing the activity of protein encoded by Nmar_0180 is required in order to ascertain whether this protein is responsible for reducing $\mathrm{Fe}$ (III) before uptake by divalent metal transporters.

\section{Surface water nitrification}

Several studies have attributed the low rates of nitrification rates in surface waters to competition with marine phytoplankton for ammonium $[16,17,25,26]$ suggesting that it is 
only when phytoplankton become light limited below the photic zone that this competition is removed. Although this is generally supported by coupled depth profiles of organic matter remineralisation (which liberates $\mathrm{NH}_{4}{ }^{+}$) and nitrification rates [70-72], rates of nitrification are significantly variable in surface waters [73] and do not always relate to ammonium availability and AOA abundance. For example, Smith and colleagues (2015) showed that even when there is ample substrate and low phytoplankton abundance, only a small fraction of the $\mathrm{NH}_{4}{ }^{+}$pool is oxidised, suggesting that an additional factor controls nitrification in surface waters. The reduced affinity of SCM1 for both DFB and unchelated Fe compared with marine phytoplankton and heterotrophic bacteria (Fig. 4) suggests that AOA are also uncompetitive for $\mathrm{Fe}$ in the photic zone providing a plausible additional factor which limits AOA growth in surface waters. Enhanced nitrification rates have been observed in oceanic surface waters during natural $\mathrm{Fe}$ fertilisation events in the Southern Ocean [74, 75] whether this is driven by an increased supply of Fe remains an interesting avenue to be explored in light of our experimental results.

Although our siderophore-uptake experiments were only performed with DFB, we hypothesise that the potential reductive uptake strategy of SCM1 may confer SCM1 with the ability to access other forms of chelated Fe. Iron reductases identified in other marine microorganisms (both prokaryotes and eukaryotes) have been shown to be 'generalist', being able to reduce a wide range of Fe-chelates [30, 54]. As SCM1 is able to reduce FeDFB, which is a hexadentate siderophore forming a very stable octahedral coordination, it is plausible that SCM1 is also able to reduce weaker bound Fe-chelates with a greater reducing potential, such as exopolysaccharides and humic acids [30]. However, this remains to be experimentally explored as other factors, such as the charge of the ligands are important determinants in the ability of ferric reductase to reduce Fe-chelates [28]. The nature of the Fereductase that SCM1 utilises may also clarify why SCM1 has a lower affinity for FeDFB compared to other marine microorganisms (Supplementary Fig. 6), ultimately shedding light on the fundamental driving factors behind the reduced competitiveness of SCM1 in the photic zone.

\section{Below the photic zone}

Despite several observations of nitrification in surface waters [73], maximum rates of nitrification and abundances of AOA are repeatedly observed at the base of the photic zone $[10,70,76]$. As described previously, this is often attributed to an enhanced supply of $\mathrm{NH}_{4}{ }^{+}$in association with remineralising organic matter $[16,71]$ and the alleviation of phytoplankton competition. However, additions of the trace metal chelator TETA in the equatorial Pacific caused a reduction in nitrification rates by up to $23 \%$ between $150-300 \mathrm{~m}$ depth [71], implicating a key role for trace metals in shaping the distribution of AOA and nitrification rates below the photic zone. As phytoplankton become light limited with increasing depth, AOA competition with phytoplankton for $\mathrm{Fe}$ would be alleviated in a similar way that has been suggested for $\mathrm{NH}_{4}^{+}[16,17]$. Marine heterotrophic bacteria also decline in abundance at the base of the photic zone $[10,77,78]$ likely driven by the reduction in dissolved organic carbon (DOC) at this depth which numerous studies have shown to be limiting to heterotrophic bacterial growth [79-82]. Iron additions alone have not been shown to enhance heterotrophic bacterial growth $[83,84]$ or have only been shown to enhance growth through an indirect effect by the enhanced phytoplankton DOC production [82-86], suggesting that it is unlikely that heterotrophic bacteria compete with $\mathrm{AOA}$ for $\mathrm{Fe}$ at the base of the photic zone. Both a reduction in the $\mathrm{Fe}$ consumption from the phytoplankton and marine bacterial communities would enable AOA relatively un-contested access to $\mathrm{Fe}$ at the base of the photic zone. We speculate that such a niche may provide AOA with sufficient Fe to reach their metabolic demands despite possessing relatively low affinity Feuptake pathways. Moreover, the reduced competition for $\mathrm{Fe}$ comes with a reduced evolutionary pressure to improve $\mathrm{Fe}$ uptake pathways and so goes some way to explaining why SCM1 appears to be a poor competitor for Fe.

\section{Conclusion}

Our work is the first to examine the role of Fe in Thaumarchaeota growth, providing evidence that the marine ammonia-oxidising archaeon Nitrosopumilus maritimus SCM1 has the highest half saturation constant for $\mathrm{Fe}^{\prime}$ of any microorganism examined to date. We showed that whilst unable to synthesise siderophores, SCM1 is able to access Fe bound to the organic siderophore DFB, and likely employs a reductive uptake pathway as part of it's Fe acquisition strategy.

Our work presents an additional explanation as to why nitrification rates are often lowest in surface waters and greatest rates are observed at the base of the photic zone $[16,70,71]$. This provides greater depth to our current understanding of AOA distribution which currently focuses largely on $\mathrm{NH}_{4}{ }^{+}$availability [16]. We suggest that AOA are potentially outcompeted for $\mathrm{Fe}$ in surface waters by phytoplankton and heterotrophic bacteria, which have a greater affinity for important $\mathrm{Fe}$ substrates, supporting findings of previous work indicating that other factors besides $\mathrm{NH}_{4}{ }^{+}$ availability regulate nitrification rates in surface waters $[11,13,17]$. We suggest that at the base of the photic zone, where phytoplankton and heterotrophic bacteria are limited by other factors (light and DOC), AOA are able to 
proliferate leading to the highest observed rates of nitrification. The curious lack of specificity in AOA Fe-uptake systems in contrast with phytoplankton and marine bacteria $[58,59]$ also agrees with the growth of AOA in an environment wherein there is reduced competition for $\mathrm{Fe}$, such as the base of the photic zone.

Future research should focus on examining Fe-uptake dynamics in additional species of marine AOA, to develop a more encompassing view of marine AOA ecophysiology, which is not purely based on the cultivation results of one marine AOA. Additionally, future work should identify the responsible ferric reductase for archaeal $\mathrm{Fe}$ uptake and determine the proteins driving the Fe demand of SCM1 at the genomic and proteomic level. Furthermore, our laboratory experiments should be corroborated with shipboard incubation experiments to determine whether AOA are Fe limited, starting in regions of persistent Fe scarcity, such as the Southern Ocean.

Acknowledgements We thank Heather Richmond (University of Aberdeen) for providing SCM1 cultures, Phillip Holdship (Oxford) for ICP-MS technical assistance, Michal Maj (Oxford) for assistance with flow cytometry analysis, and Errin Johnson (Oxford) for assistance with SEM preparation and analysis. We also extend our gratitude to the reviewers whose comments greatly improved the quality of the manuscript. This research was supported by funding from the UK Natural Environmental Research Council (NERC) and ERC Consolidator Grant APPELS: ERC-2015-COG-681746. We also acknowledge the Royal Society for a Wolfson Research Merit Award to RR.

\section{Compliance with ethical standards}

Conflict of interest The authors declare that they have no conflict of interest.

Publisher's note: Springer Nature remains neutral with regard to jurisdictional claims in published maps and institutional affiliations.

Open Access This article is licensed under a Creative Commons Attribution 4.0 International License, which permits use, sharing, adaptation, distribution and reproduction in any medium or format, as long as you give appropriate credit to the original author(s) and the source, provide a link to the Creative Commons license, and indicate if changes were made. The images or other third party material in this article are included in the article's Creative Commons license, unless indicated otherwise in a credit line to the material. If material is not included in the article's Creative Commons license and your intended use is not permitted by statutory regulation or exceeds the permitted use, you will need to obtain permission directly from the copyright holder. To view a copy of this license, visit http://creativecommons. org/licenses/by/4.0/.

\section{References}

1. Peterson ML, Wakeham SG, Lee C, Askea MA, Miquel JC. Novel techniques for collection of sinking particles in the ocean and determining their settling rates. Limnol Oceanogr Methods. $2005 ; 3: 520-32$.
2. Guidi L, Jackson GA, Stemmann L, Miquel JC, Picheral M, Gorsky G. Relationship between particle size distribution and flux in the mesopelagic zone. Deep Res Part I Oceanogr Res Pap. 2008;55:1364-74.

3. Fawcett SE, Lomas MW, Casey JR, Ward BB, Sigman DM. Assimilation of upwelled nitrate by small eukaryotes in the Sargasso Sea. Nat Geosci. 2011;4:717-22.

4. Berg GM, Balode M, Purina I, Bekere S, Béchemin C, Maestrini SY. Plankton community composition in relation to availability and uptake of oxidized and reduced nitrogen. Aquat Microb Ecol. 2003;30:263-74.

5. Glibert PM, Wilkerson FP, Dugdale RC, Raven JA, Dupont CL, Leavitt PR, et al. Pluses and minuses of ammonium and nitrate uptake and assimilation by phytoplankton and implications for productivity and community composition, with emphasis on nitrogen-enriched conditions. Limnol Oceanogr. 2016;61: 165-97.

6. Freing A, Wallace DWR, Bange HW. Global oceanic production of nitrous oxide. Philos Trans R Soc B Biol Sci. 2012;367:1245-55.

7. Löscher CR, Kock A, Könneke M, Laroche J, Bange HW, Schmitz RA. Production of oceanic nitrous oxide by ammoniaoxidizing archaea. Biogeosciences. 2012;9:2419-29.

8. Mincer TJ, Church MJ, Taylor LT, Preston C, Karl DM, DeLong EF. Quantitative distribution of presumptive archaeal and bacterial nitrifiers in Monterey Bay and the North Pacific Subtropical Gyre. Environ Microbiol. 2007;9:1162-75.

9. Wuchter C, Abbas B, Coolen MJL, Herfort L, van Bleijswijk J, Timmers $\mathrm{P}$, et al. Archaeal nitrification in the ocean. Proc Natl Acad Sci USA.. 2006;103:12317-22.

10. Karner MB, DeLong EF, Karl DM. Archaeal dominance in the mesopelagic zone of the Pacific Ocean. Nature. 2001;409:507-10.

11. Merbt SN, Stahl DA, Casamayor EO, Martí E, Nicol GW, Prosser JI. Differential photoinhibition of bacterial and archaeal ammonia oxidation. FEMS Microbiol Lett. 2012;327:41-6.

12. Horak REA, Qin W, Schauer AJ, Armbrust EV, Ingalls AE, Moffett JW, et al. Ammonia oxidation kinetics and temperature sensitivity of a natural marine community dominated by Archaea. ISME J. 2013;7:2023-33.

13. Tolar B, Powers L, Miller W, Wallsgrove N, Popp B, Hollibaugh J. Ammonia oxidation in the ocean can be inhibited by nanomolar concentrations of hydrogen Peroxide. Front Mar Sci. 2016;3:237.

14. Horak REA, Qin W, Bertagnolli AD, Nelson A, Heal KR, Han H, et al. Relative impacts of light, temperature, and reactive oxygen on thaumarchaeal ammonia oxidation in the North Pacific Ocean. Limnol Oceanogr. 2017;63:741-57.

15. Xu MN, Li X, Shi D, Zhang Y, Dai M, Huang T, et al. Coupled effect of substrate and light on assimilation and oxidation of regenerated nitrogen in the euphotic ocean. Limnol Oceanogr. 2019;9999:1-14.

16. Ward BB. Nitrification in Marine Systems. Nitrogen in the Marine. Environment. 2008;2:199-261.

17. Smith JM, Chavez FP, Francis CA. Ammonium uptake by phytoplankton regulates nitrification in the sunlit ocean. PLOS ONE 2014;9:e108173.

18. Dore JE, Karl DM. Nitrification in the euphotic zone as a source for nitrite, nitrate, and nitrous oxide at Station ALOHA. Limnol Oceanogr. 1996;41:1619-28.

19. Moore MC, Mills MM, Langlois R, Milne A, Achterberg EP, La Roche $\mathrm{J}$, et al. Relative influence of nitrogen and phosphorus availability on phytoplankton physiology and productivity in the oligotrophic sub-tropical North Atlantic Ocean. Limnol Oceanogr. 2008;53:291-305.

20. Mills MM, Ridame C, Davey M, La Roche J, Geider RJ. Iron and phosphorus co-limit nitrogen fixation in the eastern tropical North Atlantic. Nature. 2004;429:292-4. 
21. Moore MC, Mills MM, Achterberg EP, Geider RJ, Laroche J, Lucas MI, et al. Large-scale distribution of Atlantic nitrogen fixation controlled by iron availability. Nat Geosci. 2009;2:867-71.

22. Walker CB, de la Torre JR, Klotz MG, Urakawa H, Pinel N, Arp DJ, et al. Nitrosopumilus maritimus genome reveals unique mechanisms for nitrification and autotrophy in globally distributed marine crenarchaea. Proc Natl Acad Sci USA. 2010;107:8818-23.

23. Amin SA, Moffett JW, Martens-Habbena W, Jacquot JE, Han Y, Devol A, et al. Copper requirements of the ammonia-oxidizing archaeon Nitrosopumilus maritimus SCM1 and implications for nitrification in the marine environment. Limnol Oceanogr. 2013;58:2037-45.

24. Wei X, Vajrala N, Hauser L, Sayavedra-Soto LA, Arp DJ. Iron nutrition and physiological responses to iron stress in Nitrosomonas europaea. Arch Microbiol. 2006;186:107-18.

25. Urakawa H, Martens-Habbena W, Huguet C, de la Torre JR, Ingalls $\mathrm{AE}$, Devol AH, et al. Ammonia availability shapes the seasonal distribution and activity of archaeal and bacterial ammonia oxidizers in the Puget Sound Estuary. Limnol Oceanogr. 2014;59:1321-35.

26. Martens-Habbena W, Berube PM, Urakawa H, de la Torre JR, Stahl DA, Torre J, et al. Ammonia oxidation kinetics determine niche separation of nitrifying Archaea and Bacteria. Nature. 2009;461:976-9.

27. Gledhill M, Buck KN. The organic complexation of iron in the marine environment: a review. Front Microbiol. 2012;3:1-17.

28. Lis H, Kranzler C, Keren N, Shaked Y. A comparative study of iron uptake rates and mechanisms amongst marine and fresh Water cyanobacteria: prevalence of reductive iron uptake. Life. 2015;5:841-60.

29. Shaked Y, Lis H. Disassembling iron availability to phytoplankton. Front Microbiol. 2012;3:1-26.

30. Lis H, Shaked Y, Kranzler C, Keren N, Morel FMM. Iron bioavailability to phytoplankton: an empirical approach. ISME J. 2014;9:1003-13.

31. Könneke M, Bernhard AE, de la Torre JR, Walker CB, Waterbury JB, Stahl DA. Isolation of an autotrophic ammonia-oxidizing marine archaeon. Nature. 2005;437:543-6.

32. Price NM, Harrison GI, Hering JG, Hudson RJ, Nirel PMV, Palenik B, et al. Preparation and chemistry of the artificial algal culture medium aquil. Biol Oceanogr. 1989;6:443-61.

33. Gustafsson JP. Visual MINTEQ ver. 3.0. http://www.2.lwr.kth.se/ English/OurSoftware/vminteq/index.htm. 2010.

34. Zhang Q, Snow JT, Holdship P, Price D, Watson P, Rickaby REM. Direct measurement of multi-elements in high matrix samples with a flow injection ICP-MS: Application to the extended: Emiliania huxleyi Redfield ratio. J Anal At Spectrom. 2018;33:1196-208.

35. Griess P. Griess reagent: a solution of sulphanilic acid and $\alpha-$ naphthylamine in acetic acid which gives a pink colour on reaction with the solution obtained after decomposition of nitrosyl complexes. Chem Ber. 1879;12:427.

36. Sunda WG, Huntsman SA. Iron uptake and growth limitation in oceanic and coastal phytoplankton. Marine Chemistry. 1995;50:189-206.

37. Sunda WG, Huntsman SA. Interrelated influence of iron, light and cell size on marine phytoplankton growth. Nature. 1997;390:389-92.

38. Berman-Frank I, Cullen JT, Shaked Y, Sherrell RM, Falkowski PG. Iron availability, cellular iron quotas, and nitrogen fixation in Trichodesmium. Limnol Oceanogr. 2001;46:1249-60.

39. Shi D, Kranz SA, Kim J-M, Morel FMM. Ocean acidification slows nitrogen fixation and growth in the dominant diazotroph Trichodesmium under low-iron conditions. Proc Natl Acad Sci USA. 2012;109:E3094-100.
40. Schulz KG, Zondervan I, Gerringa LJA, Timmermans KR, Veldhuis MJW, Riebesell U. Effect of trace metal availability on coccolithophorid calcification. Nature. 2004;430:673-6.

41. Boatman TG, Oxborough K, Gledhill M, Lawson T, Geider RJ. An integrated response of Trichodesmium erythraeum IMS101 growth and photo-physiology to iron, $\mathrm{CO} 2$, and light intensity. Front Microbiol. 2018;10:624.

42. Shi D, Xu Y, Hopkinson BM, Morel FMM. Effect of ocean acidification on iron availability to marine phytoplankton. Science. 2010;5966:676-9.

43. Sunda WG, Huntsman SS. High iron requirement for growth, photosynthesis, and low-light acclimation in the coastal cyanobacterium Synechococcus bacillaris. Front Microbiol. 2015;6:1-13.

44. Lane ES, Semeniuk DM, Strzepek RF, Cullen JT, Maldonado MT. Effects of iron limitation on intracellular cadmium of cultured phytoplankton: Implications for surface dissolved cadmium to phosphate ratios. Mar Chem. 2009;115:155-62.

45. Marchetti A, Maldonado MT, Lane ES, Harrison PJ. Iron requirements of the pennate diatom Pseudo-nitzschia: Comparison of oceanic (high-nitrate, low-chlorophyll waters) and coastal species. Limnol Oceanogr. 2006;51:2092-101.

46. Strzepek RF, Maldonado MT, Hunter KA, Frew RD, Boyd PW. Adaptive strategies by Southern Ocean phytoplankton to lessen iron limitation: Uptake of organically complexed iron and reduced cellular iron requirements. Limnol Oceanogr.. 2011;56:1983-2002.

47. Maldonado MT, Price NM. Reduction and transport of organically bound iron by Thalassiosira oceanica (Bacillariophyceae). J Phycol. 2001;37:298-309.

48. Shaked Y, Kustka AB, Morel FMM, Erel Y. Simultaneous determination of iron reduction and uptake by phytoplankton. Limnol Oceanogr. 2004;2:137-45.

49. Hassler CS, Schoemann V. Bioavailability of organically bound $\mathrm{Fe}$ to model phytoplankton of the Southern Ocean. Biogeosciences. 2009;6:2281-96.

50. Maldonado MT, Strzepek RF, Sander S, Boyd PW. Acquisition of iron bound to strong organic complexes, with different $\mathrm{Fe}$ binding groups and photochemical reactivities, by plankton communities in Fe-limited subantarctic waters. Global Biogeochem Cycles. 2005;19:GB4S23.

51. Hudson RJM, Covault DT, Morel FMM. Investigations of iron coordination and redox reactions in seawater using $59 \mathrm{Fe}$ radiometry and ion-pair solvent extraction of amphiphilic iron complexes. Mar Chem. 1992;38:209-35.

52. Schwyn B, Neilands JB. Universal chemical assay for the detection and determination of siderophores. Anal Biochem. 1987; 160:47-56.

53. Shaked Y, Kustka AB, Morel FMM. A general kinetic model for iron acquisition by eukaryotic phytoplankton. Limnol Oceanogr. 2005;50:872-82.

54. Kranzler C, Lis H, Shaked Y, Keren N. The role of reduction in iron uptake processes in a unicellular, planktonic cyanobacterium. Environ Microbiol. 2011;13:2990-9.

55. Martin JH, Fitzwater SE. Iron deficiency limits phytoplankton growth in the north-east Pacific subarctic. Nature. 1988;331:341-3.

56. Boyd PW, Jickells T, Law CS, Blain S, Boyle EA, Buesseler KO, et al. Mesoscale iron enrichment experiments 1993-2005: synthesis and future directions. Science. 2007;315:612-7.

57. Hudson RJM, Morel FMM. Iron transport in marine phytoplankton: kinetics of cellular and medium coordination reactions. Limnol Oceanogr. 1990;35:1002-20.

58. Morrissey J, Bowler C. Iron utilization in marine cyanobacteria and eukaryotic algae. Front Microbiol. 2012;3:1-13.

59. Hogle SL, Thrash CJ, Dupont CL, Barbeau KA. Trace metal acquisition by marine heterotrophic bacterioplankton with contrasting trophic strategies. Appl Environ Microbiol. 2016;82:1613-24. 
60. Berman-Frank I, Quigg A, Finkel ZV, Irwin AJ, Haramaty L. Nitrogen-fixation strategies and $\mathrm{Fe}$ requirements in cyanobacteria. Limnol Oceanogr. 2007;52:2260-9.

61. Richier S, Macey AI, Pratt NJ, Honey DJ, Moore CM, Bibby TS. Abundances of iron-binding photosynthetic and nitrogen-fixing proteins of Trichodesmium both in culture and in situ from the North Atlantic. PLoS ONE. 2012;7:e35571.

62. Snow JT, Polyviou D, Skipp P, Chrismas NAM, Hitchcock A, Geider R, et al. Quantifying integrated proteomic responses to iron stress in the globally important marine diazotroph Trichodesmium. PLoS ONE. 2015;10:e142626.

63. Melis A. Spectroscopic methods in photosynthesis: photosystem stoichiometry and chlorophyll antenna Size. Philos Trans R Soc Lond. B. 1989;323:397-409.

64. Strzepek RF, Harrison PJ. Photosynthetic architecture differs in coastal and oceanic diatoms. Nature. 2004;431:689.

65. Qin W, Amin SA, Lundeen RA, Heal KR, Martens-Habbena W, Turkarslan $\mathrm{S}$, et al. Stress response of a marine ammoniaoxidizing archaeon informs physiological status of environmental populations. ISME J. 2018;12:508.

66. Carini P, Dupont C, Santoro AE. Patterns of thaumarchaeal gene expression in culture and diverse marine environments. Environ Microbiol. 2018;20:2112-24.

67. Santoro AE, Dupont CL, Richter RA, Craig MT, Carini P, McIlvin MR, et al. Genomic and proteomic characterization of "Candidatus Nitrosopelagicus brevis" an ammonia-oxidizing archaeon from the open ocean. Proc Natl Acad Sci USA. 2015;112:1173-8.

68. Barbeau K. Photochemistry of organic iron (III) complexing ligands in oceanic systems. Photochem Photobiol. 2006;82:1505-16.

69. Vadas A, Monbouquette HG, Johnson E, Schröder I. Identification and characterization of a novel ferric reductase from the hyperthermophilic Archaeon Archaeoglobus fulgidus. J Biol Chem. 1999;274:36715-21.

70. Santoro AE, Sakamoto CM, Smith JM, Plant JN, Gehman AL, Worden AZ, et al. Measurements of nitrite production in and around the primary nitrite maximum in the central California Current. Biogeosciences. 2013;10:7395-410.

71. Santoro AE, Saito MA, Goepfert TJ, Lamborg CH, Dupont CL, Ditullio GR. Thaumarchaeal ecotype distributions across the equatorial Pacific Ocean and their potential roles in nitrification and sinking flux attenuation. Limnol Oceanogr. 2017;62:1984-2003.

72. Shiozaki T, Ijichi M, Isobe K, Hashihama F, Nakamura KI, Ehama M, et al. Nitrification and its influence on biogeochemical cycles from the equatorial Pacific to the Arctic Ocean. ISME J. 2016;10:2184.

73. Yool A, Martin AP, Fernández C, Clark DR. The significance of nitrification for oceanic new production. Nature. 2007;447:999-1002.

74. Cavagna AJ, Fripiat F, Elskens M, Mangion P, Chirurgien L, Closset I, et al. Production regime and associated $\mathrm{N}$ cycling in the vicinity of Kerguelen Island, Southern Ocean. Biogeosciences. 2015;21:6515-28.

75. Fripiat F, Elskens M, Trull TW, Blain S, Cavagna A, Fernandez $C$, et al. Significant mixed layer nitrification in a natural ironfertilized bloom of the Southern Ocean. Global Biogeochem Cycles. 2015;29:1929-43.

76. Church MJ, Wai B, Karl DM, DeLong EF. Abundances of crenarchaeal amoA genes and transcripts in the Pacific Ocean. Environ Microbiol. 2010;12:679-88.

77. Bundy RM, Boiteau RM, McLean C, Turk-Kubo KA, McIlvin MR, Saito MA, et al. Distinct Siderophores Contribute to Iron
Cycling in the Mesopelagic at Station ALOHA. Front Mar Sci. 2018;5:1-15.

78. Campbell L, Liu H, Nolla HA, Vaulot D. Annual variability of phytoplankton and bacteria in the subtropical North Pacific Ocean at Station ALOHA during the 1991-4 ENSO event. Deep Res Part I Oceanogr Res Pap. 1997;44:167-92.

79. Kirchman DL, Keil RG, Wheeler PA. Carbon limitation of ammonium uptake by heterotrophic bacteria in the subarctic Pacific. Limnol Oceanogr. 1990;35:1258-66.

80. Van Wambeke F, Bonnet S, Moutin T, Raimbault P, Alarcón G, Guieu C. Factors limiting heterotrophic bacterial production in the southern Pacific Ocean. Biogeosciences. 2008;5:833-45.

81. Eiler A, Langenheder S, Bertilsson S, Tranvik LJ. Heterotrophic bacterial growth efficiency and community structure at different natural organic carbon concentrations. Appl Environ Microbiol. 2003;69:3701-9.

82. Kirchman DL. The uptake of inorganic nutrients by heterotrophic bacteria. Microb Ecol. 1994;28:255-71.

83. Kirchman DL, Meon B, Cottrell MT, Hutchins DA, Weeks D, Bruland KW. Carbon versus iron limitation of bacterial growth in the California upwelling regime. Limnol Oceanogr. 2000;45:1681-8.

84. Church MJ, Hutchins DA, Ducklow HW. Limitation of bacterial growth by dissolved organic matter and iron in the Southern Ocean. Appl Environ Microbiol. 2000;66:455-66.

85. Cochlan WP. The heterotrophic bacterial response during a mesoscale iron enrichment experiment (IronEx II) in the eastern equatorial Pacific Ocean. Limnol Oceanogr. 2001;46:428-35.

86. Pakulski JD, Coffin RB, Kelley CA, Holder SL, Downer R, Aas P, et al. Iron stimulation of Antarctic bacteria. Nature. 1996;383:133-4.

87. Johnson KS, Michael Gordon R, Coale KH. What controls dissolved iron concentrations in the world ocean? Mar Chem. 1997;57:137-61.

88. Planquette H, Statham PJ, Fones GR, Charette MA, Moore CM, Salter I, et al. Dissolved iron in the vicinity of the Crozet Islands, Southern Ocean. Deep Res Part II Top Stud Oceanogr. 2007;54:1999-2019.

89. Klunder MB, Bauch D, Laan P, De Baar HJW, Van Heuven S, Ober S. Dissolved iron in the Arctic shelf seas and surface waters of the central Arctic Ocean: Impact of Arctic river water and icemelt. J Geophys Res Ocean. 2012;117:C1.

90. Tagliabue A, Mtshali T, Aumont O, Bowie AR, Klunder MB, Roychoudhury AN, et al. A global compilation of dissolved iron measurements: focus on distributions and processes in the Southern Ocean. Biogeosciences. 2012;9:2333-49.

91. Fitzsimmons JN, Conway TM, Lee JM, Kayser R, Thyng KM, John SG, et al. Dissolved iron and iron isotopes in the southeastern Pacific Ocean. Global Biogeochem Cycles. 2016;30:1372-95.

92. Rijkenberg MJA, Middag R, Laan P, Gerringa LJA, Van Aken HM, Schoemann V, et al. The distribution of dissolved iron in the West Atlantic Ocean. PLoS ONE. 2014;9:e101323.

93. Wu J, Boyle E. Iron in the Sargasso Sea: Implications for the processes controlling dissolved $\mathrm{Fe}$ distribution in the ocean. Global Biogeochem Cycles. 2002;16:33-1.

94. Bergquist BA, Boyle EA. Dissolved iron in the tropical and subtropical Atlantic Ocean. Glob Biogeochem Cycles. 2006;20: GB1015. 